Ann. Biol. anim. Bioch. Biophys., 1978, 18 (4), 893-898.

\title{
The cellular sources of sex steroids in teleost gonads
}

\author{
par W. S. HOAR, Y. NAGAHAMA
}

Deparfment of Zoology, Universify of British Columbia, Vancouver, Canada, V6T 1 W5.

\begin{abstract}
Summary. Histochemical and ultrastructural studies of gonads from goldfish Carassius auratus and several species of salmon (genus Oncorhynchus) indicate that the Leydig or interstitial cells of the testis and special cells of the theca interna of the ovary are the major sources of gonadal steroids. Lobule boundary cells are considered homologous with the Sertoli cells of the testis and the granulosa cells of the ovary. In our preparations, lobule boundary, Sertoli and granulosa cells do not show convincing evidence of steroidogenesis.
\end{abstract}

Although biochemical studies have shown that teleost fishes - like other vertebrates - produce gonadal steroids, the cellular sources of these hormones remain uncertain. Relevant literature is summarized in recent reviews (Lofts and Bern, 1972 ; Guraya, 1976a, b) and in the papers cited below. Electron microscopy and improved methods of histochemistry now offer possibilities for localizing the sources of these hormones. To this end, gonads of goldfish Carassius auratus and salmon (especially the coho Oncorhynchus kisutch and pink 0 . gorbuscha) have been examined at different times during the sexual cycle.

\section{Leydig or Interstitial cells.}

Our findings confirm those of most workers and assign to these cells the primary role in the synthesis of androgens. These large polygonal cells are usually located within the triangular interlobular spaces (figs 1 and 2), and are characterized by smooth endoplasmic reticula and mitochondria with tubular cristae (fig. 3) ; they contain many lipid droplets (fig. 2) and react positively to tests for enzymes concerned with androgen synthesis. Furthermore, gonadotropin treatment caused marked stimulation of the interstitial cells in immature goldfish (unpublished). These findings confirm several recent studies of Leydig cells using similar techniques (Nicholls and Graham, 1972 ; Gresik et al., 1973 ; Van den Hurk ef al., 1974).

\section{Lobule Boundary cells or Sertoli cells.}

Lobule boundary cells, described in several teleosts, have been homologized with Leydig cells by some workers (O'Halloran and Idler, 1970) and with the Sertoli 


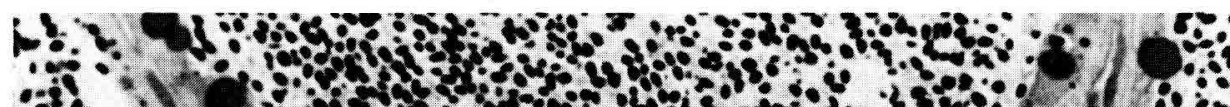

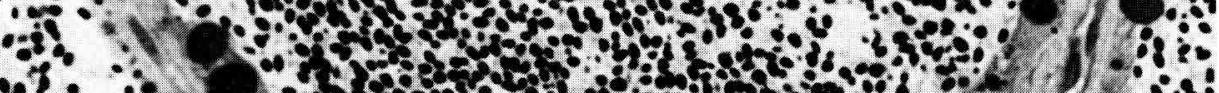

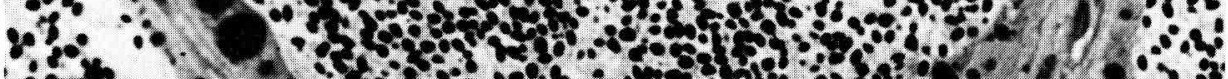

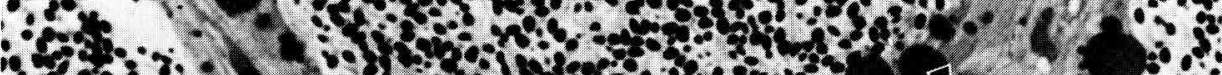
is $253^{3} \cdot 1$. -60.5:

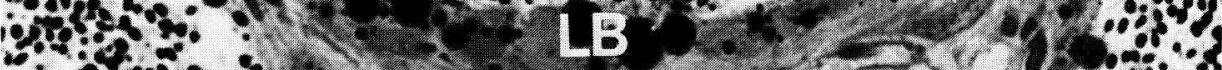
if

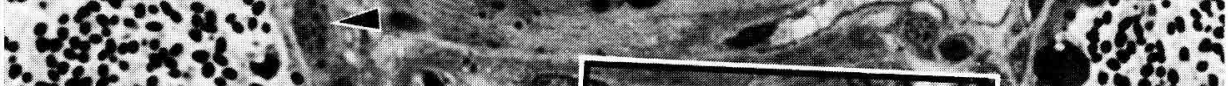

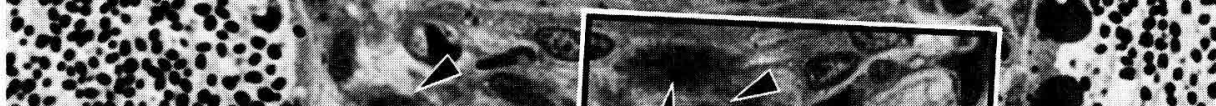

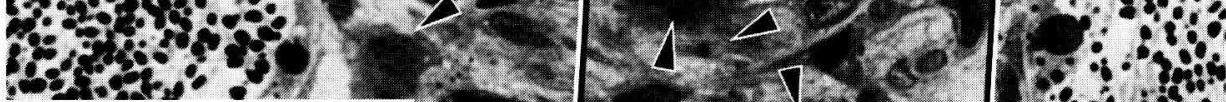
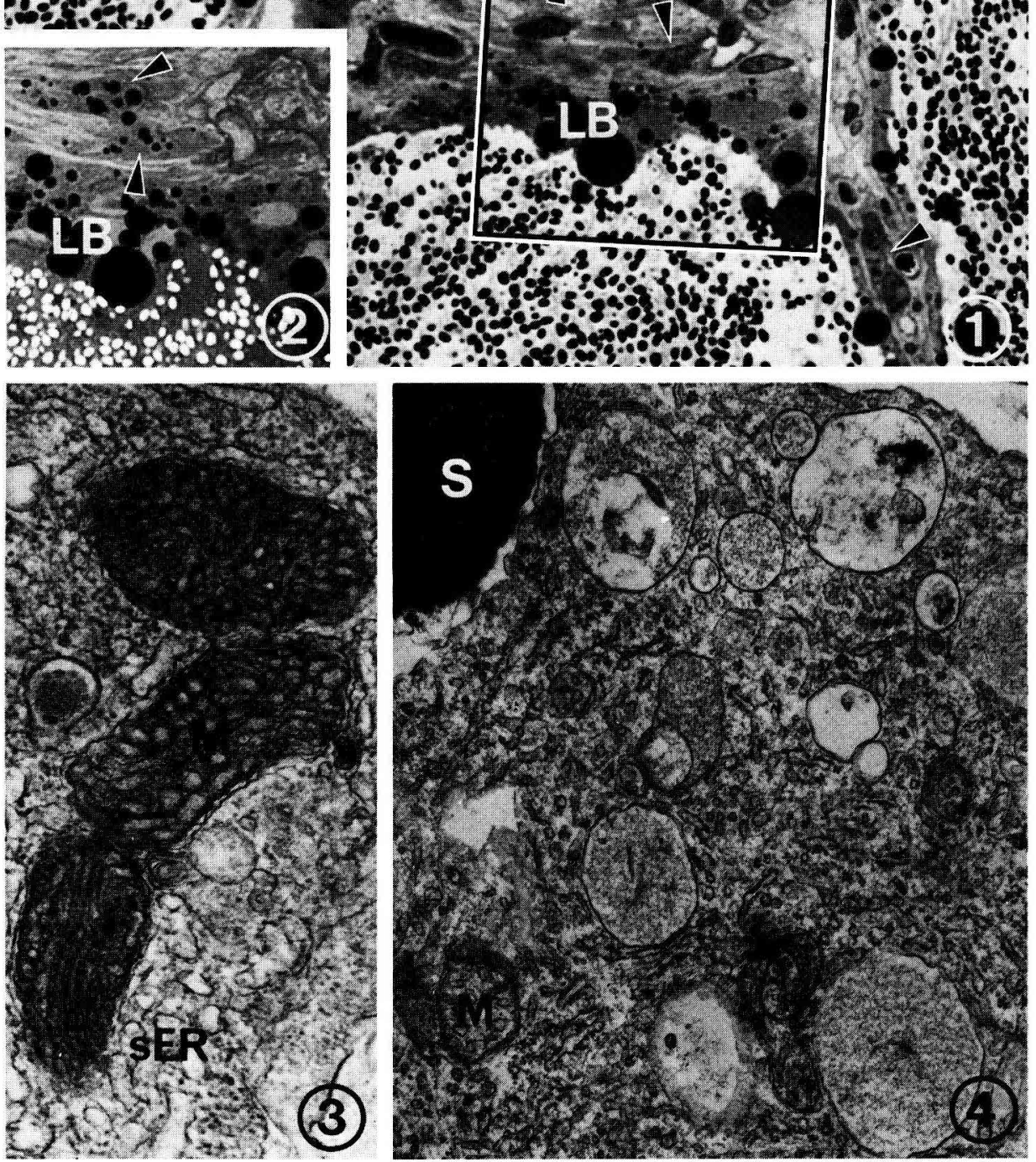
cells by others (Nicholls and Graham, 1972 ; Billard ef al., 1972 ; Van den Hurk ef al., 1974 ; Grier, 1976). In our preparations, lobule boundary cells lack the ultrastructural characteristics of Leydig cells and are clearly homologous with the Sertoli cells. Although they contain many large lipid droplets (figs 1 and 2), they react negatively in histochemical tests for steroidogenesis. They occur in close proximity to spermatids and developing sperm, and possess some ultrastructural features suggesting phagocytosis and an involvement in transporting metabolites (fig. 4). Although Sertoli cells may synthesize steroids in some vertebrates, we found no evidence for this in salmon or goldfish.

\section{Granulosa and Theca Interna.}

Ovarian steroidogenesis has usually been attributed to the granulosa - or its postovulatory derivatives (Lambert and van Oordt, 1974 and reviews cited). However, granulosa cells of goldfish and salmon do not possess ultrastructural features typical of steroid-synthesizing cells but contain organelles suggestive of protein synthesis. Moreover, histochemical tests proved negative except for a very brief period following ovulation in the goldfish (Nagahama ef al., 1976). The evidence is equivocal. Although a transient period of steroidogenesis may occur in the postovulatory granulosa of the goldfish, this layer does not appear to be a major centre for steroidogenesis at any time in the ovarian cycles of the goldfish or salmon. We conclude that granulosa cells are concerned with oogenesis (formation of zona pellucida and yolk) and not hormone synthesis.

Ovarian hormones are apparently synthesized in special cells of the theca interna. These cells occur singly or in small nests and are cytologically similar to Leydig cells (Nagahama ef al., 1976) with which they appear to be homologous. Moreover, the special cells seem to retain their steroidogenic capacities for considerable time after

FIG. 1. - Epon section ( $1 \mu$ ) of a portion of the testis of a mature pink salmon. Interstitial cells (arrows) are seen in the interlobular space. Lobule boundary celis (LB) have many large lipid droplets. Methylene blue-azur II. $\times 700$.

FIG. 2. - Sudan black B stained-epon section $(1 \mathrm{um})$ of square area outlined in figure 1 . Note darkly stained lipid droplets in interstitial cells (arrows) and lobule boundary cells (LB). $\times 700$.

FIG. 3. - Electron micrograph of a portion of the interstitiol cell of a mature coho. Note large mitochondria $(M)$ containing tubular cristae and intramitochondrial granules, and well-developed smooth endoplasmic reticulum (sER). $\times 40000$.

FIG. 4. - Electron micrograph of a portion of the lobule boundary cell of a mature coho. A sperm head $(S)$ is found in close association with a lobule boundary cell. $M$, mitochondrion. $\times 20000$. 


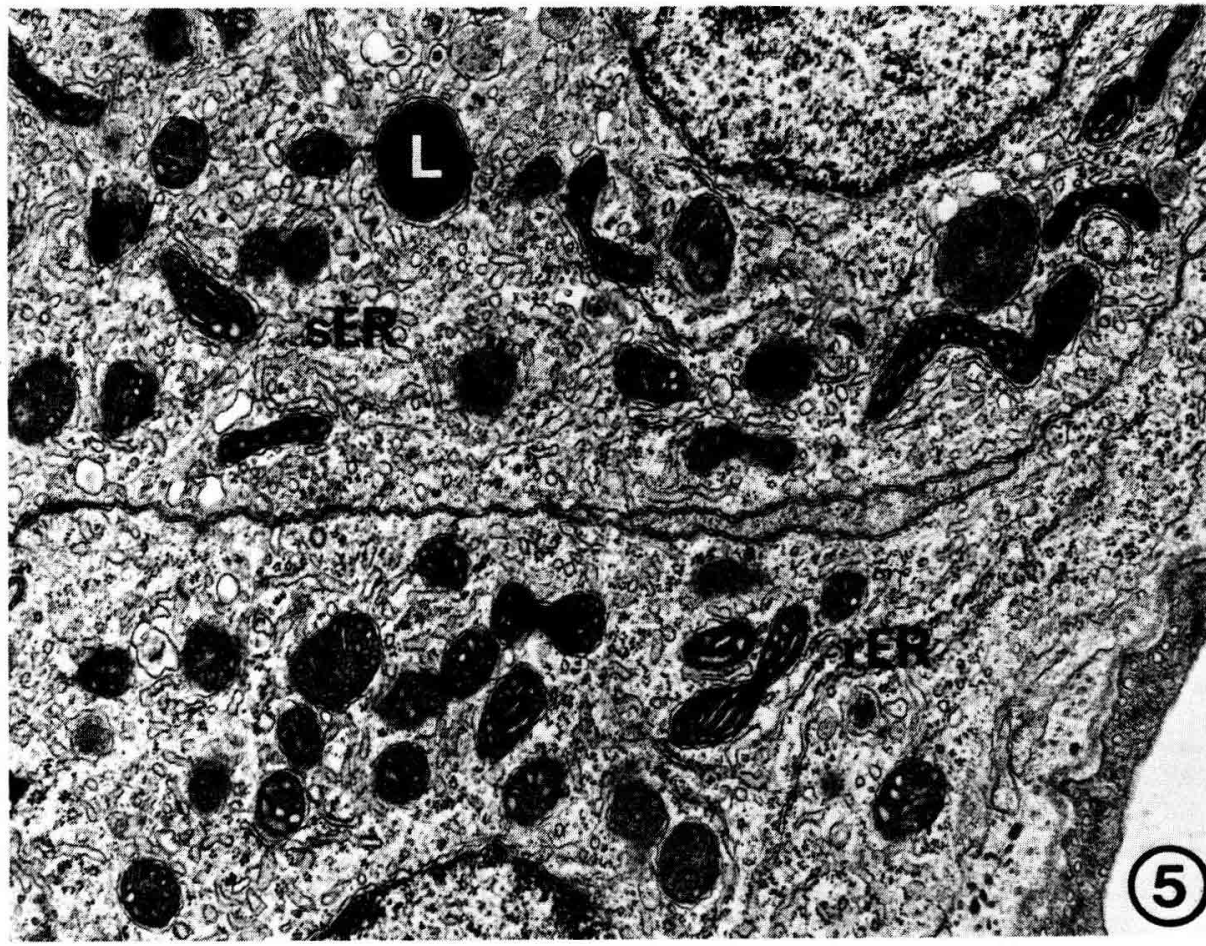
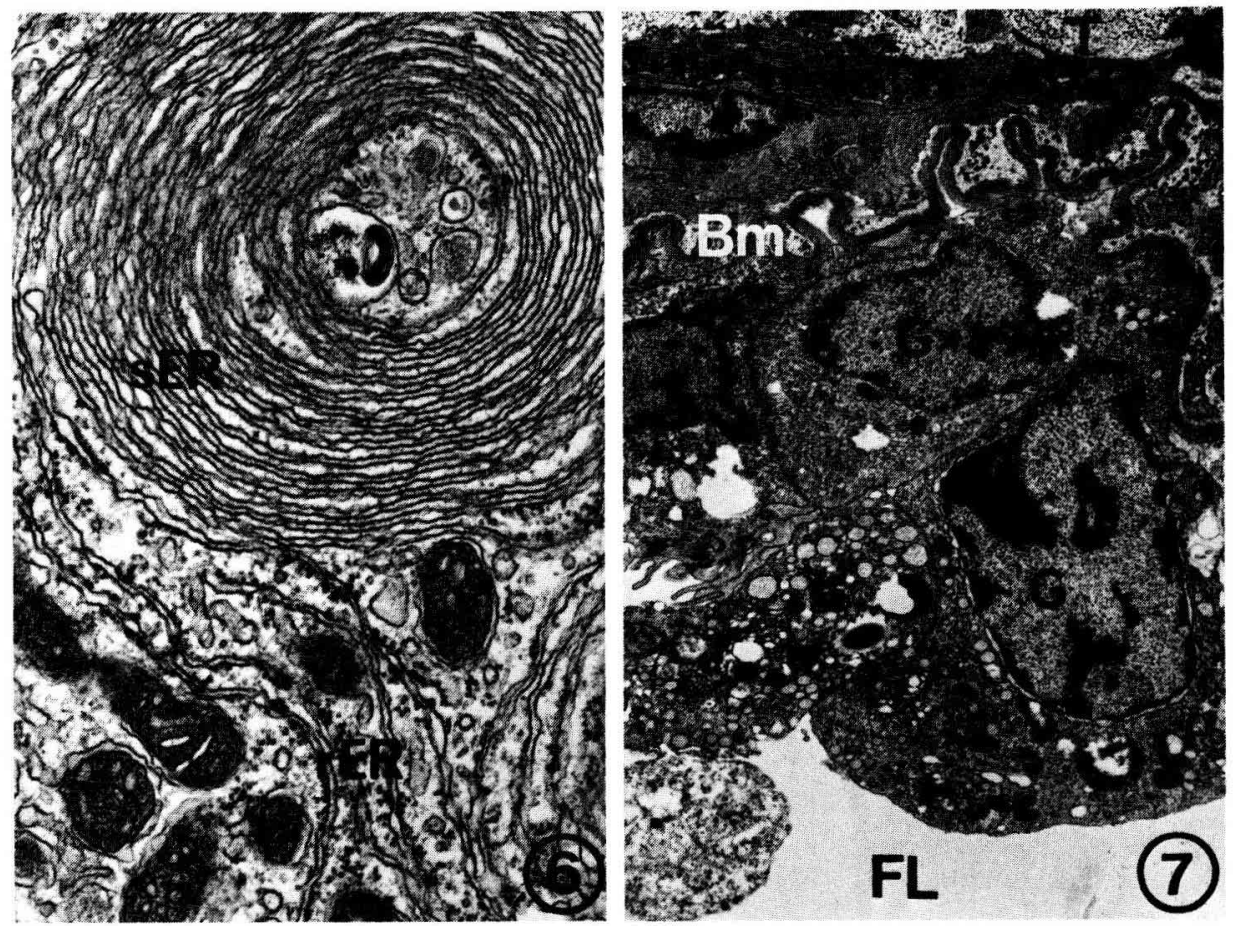
ovulation (figs 5 and 6), while granulosa cells degenerate soon after ovulation (fig. 7). Several recent studies have reached similar conclusions in other teleosts (Nicholls and Maple, 1972 ; Saidapur and Nadkarni, 1976).

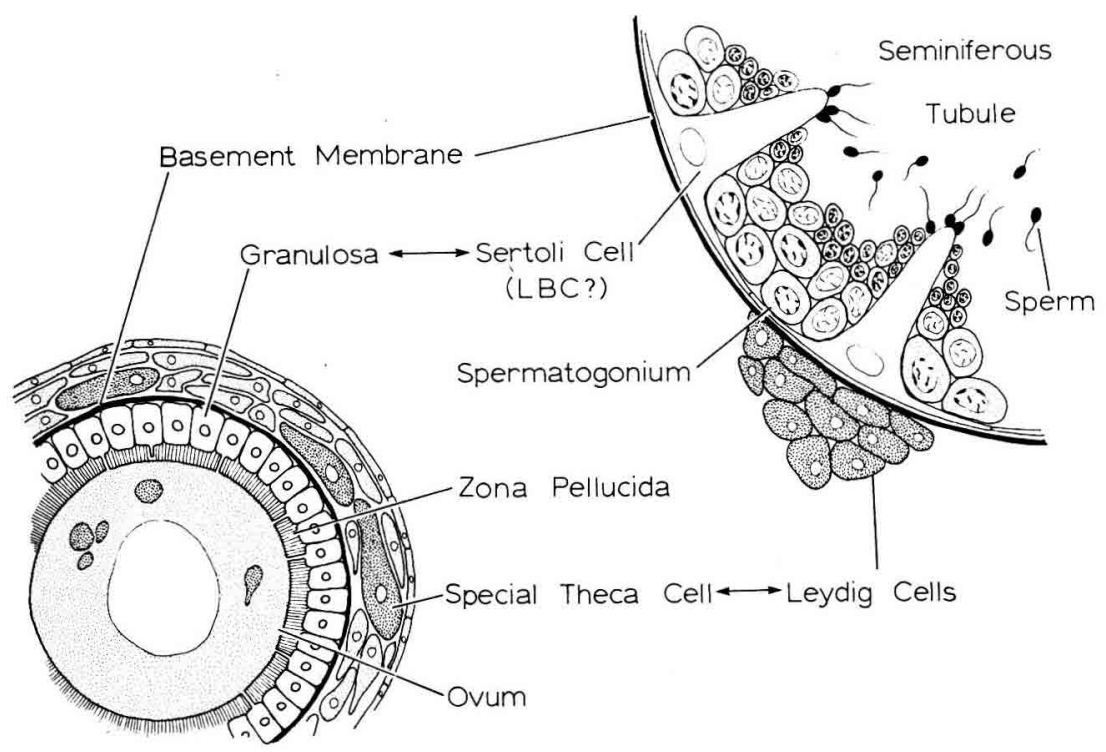

FIG. 8. - Diagram showing steroid synthesizing cells in teleost gonads.

LBC, lobule boundary cell.

Figure 8 summarizes the probably sources of sex steroids in teleost gonads, based on several recent studies and our examination of goldfish and salmon. The interstitial cells in the testis and the special theca cells in the ovary are considered the main sources.

Symposium sur la Reproduction des Poissons Paimpont, France, 19-21 septembre 1977.

FIG. 5. - Electron micrograph of portions of two special theca cells of the post-ovulatory follicle of a coho. Note many mitochondria with fubular cristae, and well-developed smooth (sER) and rough endoplasmic reticulum (rER). L, lipid droplet; Ly, lysosome. $\times 15000$.

FIG. 6. - Electron micrograph of a portion of a special theca cell of the post-ovulatory follicle of a coho. Note extensive smooth endoplasmic reticulum (sER) arranged in the form of concentric whorls. $\times 30000$.

FIG. 7. - Electron micrograph of a portion of the post-ovulatory follicle of a coho. Note degenerated granulosa (G) cells. Bm, basement membrane ; FL, follicular lumen ; T, theca layer. $\times 4000$. 
Résumé. L'étude histochimique et ultrastructurale des gonades du poisson rouge, Carassius auratus, et de plusieurs espèces de saumon (genre Oncorhynchus) montre que les cellules de Leydig ou cellules interstitielles du testicule et les cellules spéciales de la thèque interne de l'ovaire sont les principales sources des stéroïdes gonadiques. Les « lobules boundary cells » peuvent être assimilées aux cellules de Serioli du testicule et aux cellules de la granulosa de l'ovaire de mammifère. Les «lobules boundary cells», les Sertoli et les cellules de granulosa ne montrent pas de signes nets d'activité stéroïdogène.

\section{References}

BILLARD R., JALABERT B., BRETON B., 1972. Les cellules de Sertoli des Poissons Téléostéens. I. Etude ultrastructurale. Ann. Biol. anim. Bioch. Biophys., 12, 19-32.

GRESIK E.W., QUIRK J. G., HAMILTON J. B., 1973. A fine structural and histochemical study of the Leydig cell in the testis of the teleost, Oryzias latipes (Cyprinifontiformes). Gen. comp. Endocrinol, 20, 86-98.

GRIER H. J., 1976. Sperm development in the teleost Oryzios latipes. Cell Tiss. Res., 168, 419-431.

GURAYA S. S., 1976a. Recent advances in the morphology, histochemistry and biochemistry of steroid-synthesizing cellular sites in the non-mammalian vertebrate ovary. Int. Rev. Cytol., 44, 365-409.

GURAYA S. S., 1976b. Recent advances in the morphology, histochemistry and biochemistry of steroid-synthesizing cellular sites in the testes of nonmammalian vertebrates. Int. Rev. Cyfol., 47, 99-136.

LAMBERT J. G. D., VAN OORDT P. G.W. J., 1974. Ovarium hormones in teleosts. Fortschr. Zool., 22, 340-349.

LOFTS B., BERN H. A., 1972. The functional morphology of steroidogenic tissues, 37-125. In IDLER D. R., Sferoids in non-mammalian veriebrates, Acad. Press, New York.

NAGAHAMA Y., CHAN K., HOARW. S., 1976. Histochemistry and ultrastructure of pre- and post-ovulatory follicles in the ovary of the goldfish, Carassius auratus. Can. J. Zool., 54, 11281139.

NICHOLLS T. J., GRAHAM G. P., 1972. The ultrastructure of lobule boundary cells and Leydig cell homologs in the testis of a cichlid fish, Cichlasoma nigrofasciatus. Gen. comp. Endocrinol., 19, 133-146.

NICHOLLS T. J., MAPLE G., 1972.Ultrastructural observations on possible sites of steroid biosynthesis in the ovarian follicular epithelium of two species of cichlid fish, Cichlasoma nigrofosciatum and Hoplochromis multicolor. Z. Zellforsch., 128, 317-335.

O'HALLORAN M. J., IDLER D. R., 1970. Identification and distribution of the Leydig cell homolog in the testis of sexually mature Atlantic salmon (Salmo salar). Gen. comp. Endocrinol., 15, 361-364.

SAIDAPUR S. K., NADKARNI V. B., 1976. Steroid synthesizing cellular sites in the ovary of catfish, Mystus cavasius : a histochemical study. Gen. comp. Endocrinol., 30, 457-461.

VAN DEN HURK R., MEEK J., PEUTE J., 1974. Ultrastructural study of the testis of the black molly (Mollienisia latipinna) Sertoli cells and Leydig cells. Proc. kon. ned. Akad. Wefensch., Ser. C. 77, 470-476. 